\title{
The Use of Landsat 7 Enhanced Thematic Mapper Plus for Mapping Leafy Spurge
}

\author{
Carol S. Mladinich, ${ }^{1}$ Monica Ruiz Bustos, ${ }^{2}$ Susan Stitt, ${ }^{3}$ Ralph Root, ${ }^{4}$ \\ Karl Brown, ${ }^{5}$ Gerald L. Anderson, ${ }^{6}$ and Steve Hager ${ }^{7}$
}

\begin{abstract}
Authors are ${ }^{1}$ Physical Scientist and ${ }^{4}$ Remote Sensing Physical Scientist (deceased), U.S. Geological Survey, Rocky Mountain Geographic Science Center, Lakewood, CO 80225; ${ }^{2}$ Fulbright Scholar, Instituto Geografico Nacional, Madrid, Spain;

${ }^{3}$ Remote Sensing Biologist and ${ }^{5}$ Program Analyst, USGS, Center for Biological Informatics, Lakewood, CO 80225;

${ }^{6}$ Ecologist, USDA, Agricultural Research Service, Northern Plains Agricultural Research Laboratory, Sidney, MT 59270; and ${ }^{7}$ GIS Specialist, NPS, Theodore Roosevelt National Park, Medora, ND 58645.
\end{abstract}

\begin{abstract}
Euphorbia esula L. (leafy spurge) is an invasive weed that is a major problem in much of the Upper Great Plains region, including parts of Montana, South Dakota, North Dakota, Nebraska, and Wyoming. Infestations in North Dakota alone have had a serious economic impact, estimated at \$87 million annually in 1991, to the state's wildlife, tourism, and agricultural economy. Leafy spurge degrades prairie and badland ecosystems by displacing native grasses and forbs. It is a major threat to protected ecosystems in many national parks, national wild lands, and state recreational areas in the region. This study explores the use of Landsat 7 Enhanced Thematic Mapper Plus (Landsat) imagery and derived products as a management tool for mapping leafy spurge in Theodore Roosevelt National Park, in southwestern North Dakota. An unsupervised clustering approach was used to map leafy spurge classes and resulted in overall classification accuracies of approximately $63 \%$. The uses of Landsat imagery did not provide the accuracy required for detailed mapping of small patches of the weed. However, it demonstrated the potential for mapping broad-scale (regional) leafy spurge occurrence. This paper offers recommendations on the suitability of Landsat imagery as a tool for use by resource managers to map and monitor leafy spurge populations over large areas.
\end{abstract}

\section{Resumen}

Euphorbia esula L. ("Leafy spurge”) es una maleza invasora que es un problema serio en muchas partes de la regíon de las Planicies Altas, incluyendo partes de Montana, South Dakota, North Dakota, Nebraska y Wyoming. Solamente en North Dakota, las infestaciones han tenido un serio impacto económico estimado (en 1991) en \$ 87 millones anuales para la economía estatal del turismo, la fauna silvestre y la agricultura. El "Leafy spurge" degrada las praderas y los ecosistemas "Badland" al desplazar los zacates y hierbas nativas. Es una amenaza mayor para los ecosistemas protegidos de muchos parques nacionales, tierras nacionales naturales y áreas recreativas estatales de la región. Este estudio explora el uso de imágenes y productos derivados del Mapeador Temático Mejorado Landsat 7 Plus (Landsat) como herramienta de manejo para mapear el "Leafy spurge” en el Parque Nacional Thedore Roosvelt, del sudoeste de North Dakota. Un método no supervisado de aglomeración fue usado para mapear clases de "Leafy spurge" y resultó en certeza general de clasificación de aproximadamente $63 \%$. El uso de imágenes de Landsat 7 no provee la cereza requerida para un mapeo detallado de parches pequeños de la maleza. Sin embargo, demostró el potencial para mapear a una escala mayor (regional) la ocurrencia de "Leafy spurge." Este artículo ofrece recomendaciones de la factibilidad de las imágenes del Landsat 7 como una herramienta para de los manejadores de recursos para mapear y monitorear poblaciones de "Leafy spurge" en grandes áreas.

Key Words: Euphorbia esula L., remote sensing, unsupervised classification, invasive species, Theodore Roosevelt National Park

\section{INTRODUCTION}

Euphorbia esula L. (leafy spurge) is an invasive weed that impacts much of the Upper Great Plains including Montana, South Dakota, North Dakota, Nebraska, and Wyoming. Infestations in North Dakota alone have had a serious eco-

Research was funded in part by the US Department of Agriculture, Agricultural Research Service and the US Geological Survey.

Any use of trade, product, or firm names is for descriptive purposes only and does not imply endorsement by the US Government.

Correspondence: Carol S. Mladinich, USGS, RMGSC, PO Box 25046 MS 516, Lakewood, C0 80225. Email: csmladinich@usgs.gov

Manuscript received 27 February 2006; manuscript accepted 14 June 2006. nomic impact, estimated at $\$ 87$ million annually in 1991 , to the state's wildlife, tourism, and agricultural economy (Andrascik 1994). Leafy spurge degrades prairie and badland ecosystems by displacing native grasses and forbs. It is a major threat to protected ecosystems in many national parks, national wild lands, and state recreational areas in the region. This research effort was part of a larger study that investigated multisource imagery to map leafy spurge. The research focus was the use of Landsat 7 Enhanced Thematic Mapper Plus (ETM+) imagery as a leafy spurge management tool for Theodore Roosevelt National Park (TRNP) and the surrounding region. The park has already spent years of research to develop efficient and costeffective methods for controlling leafy spurge. In spite of this aggressive control program, leafy spurge continues to be the primary resource management issue facing TRNP. 
Mapping the extent and change of vegetation species, such as leafy spurge, was typically accomplished with ground surveys and aerial photography. However, ground surveys are time consuming, costly, and can be difficult because of the enormity and inaccessibility of many regions to be mapped (Everitt et al. 2001). Aerial photography remains a mainstay of vegetation mapping, but again is labor intensive, expensive, and often difficult to acquire because of weather conditions. Satellite imagery may be used to complement traditional methods of vegetation mapping. The use of remote sensing techniques and, in particular, Landsat data, to map vegetation is well established (Carneggie et al. 1983; Campbell 1987; Anderson et al. 1993; Everitt et al. 2001). Remote sensing techniques offer rapid turnaround and revisit capabilities, as well as being more cost effective than ground surveys. State-of-the-art remote sensing can potentially provide data at frequent intervals needed to quantify changes in vegetation cover.

The U.S. Geological Survey (USGS) was a part of a larger integrated U.S. Department of Agriculture (USDA), Agricultural Research Service (ARS) effort to attack the leafy spurge problem called The Ecological Area-Wide Management (TEAM) of Leafy Spurge (TLS). TLS was designed to conduct research and demonstrate the effectiveness of using integrated pest management systematically over large regions. The USGS component of the project was to investigate the use of data from multiple sensor platforms to develop the best tool (or sets of tools) needed for monitoring and mapping leafy spurge. Specific requirements from TRNP included a monitoring tool that was cost efficient, timely, scale appropriate, and easily analyzed. The objectives of this paper are to 1) discuss the use of Landsat 7 ETM+ satellite imagery for meeting manager needs, and 2) comment on its suitability as an operational monitoring tool.

\section{MATERIALS AND METHODS}

\section{Study Site}

Theodore Roosevelt National Park was established on 25 April 1947. The park consists of 3 separate units totaling 28521 ha. The South Unit $\left(46^{\circ} 53^{\prime} 1.309^{\prime \prime} \mathrm{N}, 47^{\circ} 1^{\prime} 16.503^{\prime \prime} \mathrm{N}\right.$ [minimummaximum]; $103^{\circ} 36^{\prime} 35.277^{\prime \prime} \mathrm{W}, 103^{\circ} 18^{\prime} 1.024^{\prime \prime} \mathrm{W}$ [minimummaximum] shown in Fig. 1) was the study area for this project (47000 acres). The park preserves the badlands ecosystems surrounding the Little Missouri River and the cultural resources resulting from the human habitation of the area. Park resource managers strive to protect and maintain the native species found in the park. Leafy spurge is the most invasive species with the greatest potential for damaging native plant communities in the region. Leafy spurge is now found throughout the southern unit of the park and in all habitat types. However, the plant is hydrophilic and more readily establishes in streambeds, drainages, and woodlands within draws. The wetter environments in the park are by far the most productive and ecologically diverse, thus infestations of leafy spurge in these areas magnify the impact of the weed (Anderson et al. 1996) and substantially reduce habitat availability for native animal species, such as buffalo, elk, and deer.

Leafy spurge has very few natural enemies capable of controlling the weed's expansion. Prior to the late 1980s, typical control methods consisted primarily of herbicide application with limited uses of sheep and goat grazing. In the late
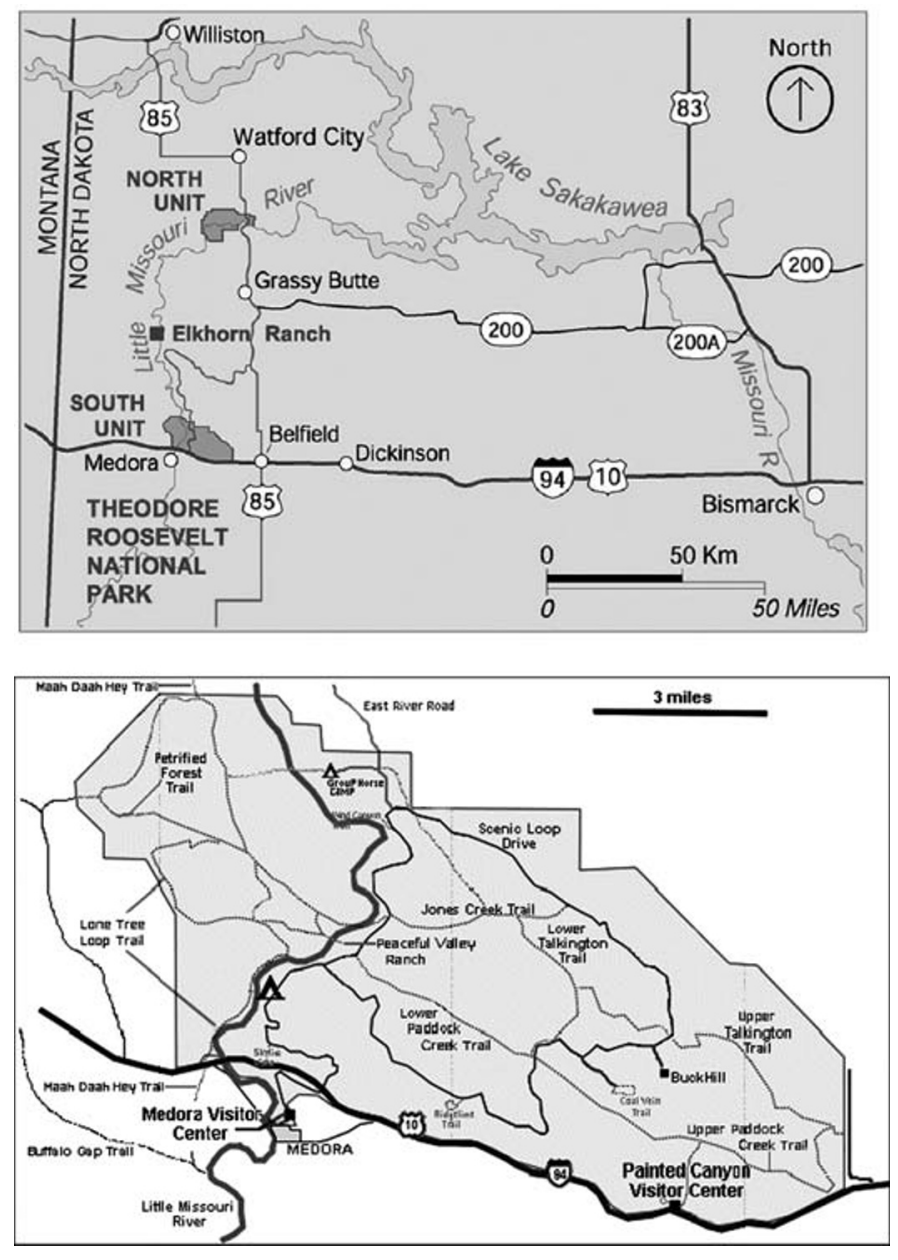

Figure 1. Theodore Roosevelt National Park and Environs. The National Park Units are shown as dark gray polygons (top). The South Unit of the Park was the study area for the project (bottom).

1980s, the park embarked on an aggressive eradication campaign in cooperation with the USDA ARS, Animal and Plant Health Inspection Service (APHIS), and North Dakota State University. An integrated approach using helicopter-based herbicide application, ground spraying, and the release of host-specific insect species (biological control agents) was adopted and continues to this date.

\section{Background}

In 1993, the ARS flew the first low-altitude aerial photography mission over the park, mapping the leafy spurge infestation using visual photointerpretation (Anderson et al. 1996). Seven hundred and twenty-five ha of leafy spurge were digitized, georeferenced, and imported into a geographic information system. Using this base of spatial information, the ARS generated map products that allowed park managers to gather and direct resources more efficiently toward infestation control. Biological control insectaries located in North Dakota and Montana provided insects for release beginning in 1994. By the late 1990s, more than 2000 insect release sites had been established, forming a dense network of insectaries throughout the infestation. Recently, the park has seen landscape-scale reductions in leafy spurge as the insect network coalesces; 
Table 1. Landsat $7 \mathrm{ETM}+$ channel spectral and spatial resolution (Campbell 1987; NASA Goddard Space Flight Center 2005).

\begin{tabular}{|c|c|c|c|}
\hline \multirow[b]{2}{*}{$\begin{array}{l}\text { Band } \\
\text { number }\end{array}$} & \multicolumn{3}{|c|}{ Landsat 7 ETM+ } \\
\hline & Description & $\begin{array}{c}\text { Spectral } \\
\text { range }(\mu \mathrm{m})\end{array}$ & $\begin{array}{l}\text { Ground } \\
\text { resolution }(\mathrm{m})\end{array}$ \\
\hline 1 & $\begin{array}{l}\text { Blue-green } \\
\text { Separation of soil and vegetation, } \\
\text { coastal water mapping }\end{array}$ & $0.45-0.52$ & 30 \\
\hline 2 & $\begin{array}{l}\text { Green } \\
\text { Vegetation discrimination and } \\
\text { health monitoring, man-made } \\
\text { feature identification }\end{array}$ & $0.52-0.60$ & 30 \\
\hline 3 & $\begin{array}{l}\text { Red } \\
\text { Chlorophyll absorption, plant } \\
\text { species identification, man-made } \\
\text { feature identification }\end{array}$ & $0.63-0.69$ & 30 \\
\hline 4 & $\begin{array}{l}\text { Near infrared } \\
\text { Delineation of water bodies }\end{array}$ & $0.76-0.90$ & 30 \\
\hline 5 & $\begin{array}{l}\text { Mid infrared } \\
\text { Vegetative moisture content }\end{array}$ & $1.55-1.75$ & 30 \\
\hline 6 & $\begin{array}{l}\text { Far (thermal) infrared } \\
\text { Surface temperature, plant heat } \\
\text { stress, volcanic monitoring }\end{array}$ & $10.40-12.56$ & 60 \\
\hline 7 & $\begin{array}{l}\text { Mid infrared (short wave IR) } \\
\text { Hydrothermal mapping, mineral } \\
\text { and rock discrimination }\end{array}$ & $2.08-2.35$ & 30 \\
\hline 8 & Panchromatic & $0.52-0.90$ & 15 \\
\hline
\end{tabular}

however, leafy spurge still infests an estimated $10 \%$ of the land base and $25 \%$ of the riparian areas (Anderson et al. 1999).

\section{Image Processing and Georeferencing}

A single Landsat image collected on 6 July 2001 was acquired from the USGS, Eros Data Center in Sioux Falls, South Dakota. The scene date coincided with other imagery collected from the Earth Observing-1 Advanced Land Imager (satellite), Airborne Visible and Infrared Imaging Spectrometer, Compact Airborne Spectrographic Imager-2, Earth Observing-1 Hyperion (satellite). The Landsat data were requested with Level $1 \mathrm{R}$ correction (L1R) and all bands, with the exception of the thermal band, were used for this study (Table 1) (NASA Goddard Space Flight Center 2005). Level 1R correction includes radiometric correction (radiance), no geometric correction (for topographic relief), and, because of the scanning process, scan lines are reversed and nominally aligned. The Landsat data were georeferenced using a general polynomial algorithm and resampled to $30 \mathrm{~m}$ spatial resolution using a nearest neighbor algorithm. Visual comparison of the corrected imagery with high-definition ground features in the corresponding digital orthophoto quadrangles showed maximum displacements to be no greater than 1 Landsat pixel. Precise georeferencing was important in this study to ensure good spatial agreement with ground data collected for verification and accuracy assessment. Therefore, a subset of the full Landsat scene, that covered the entire South Unit of TRNP, was extracted and georeferenced using the Leica Geosystems Geospatial Imaging Erdas Imagine image processing software. The data were also pansharpened using the PCI
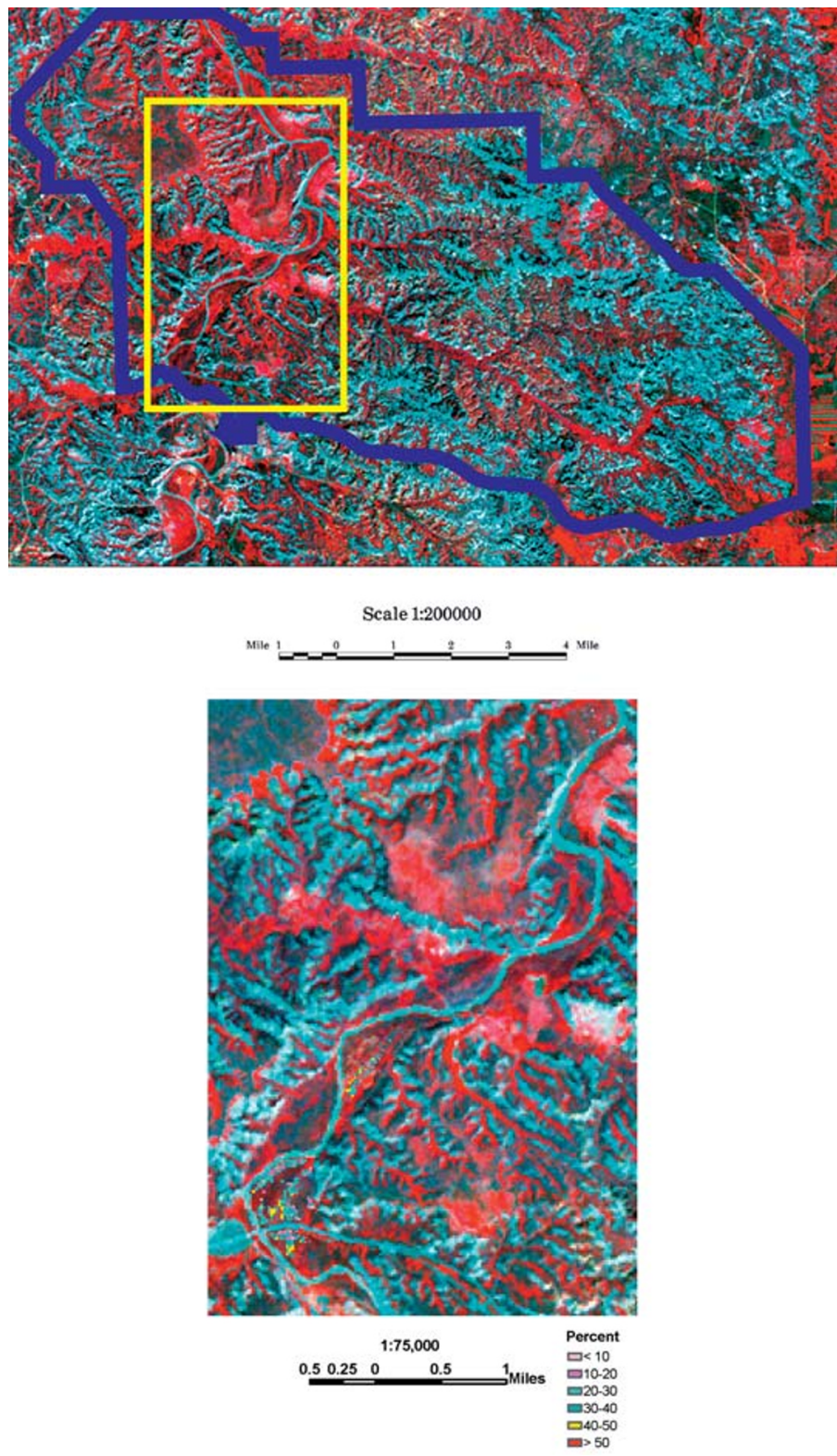

Figure 2. Landsat (6 July 2001) subset of the South Unit of TRNP (blue line) (bands 4, 3, and 2 are shown in RGB order producing a false color infrared image) (top). The yellow outline shows the area of ground reference data, Set 1. Ground Reference data, Set 1, used for classification, consisting of a $32 \times 32 \mathrm{~m}$ grid with the percentage of leafy spurge coverage in each grid (bottom).

Geomatica Pansharpening module. Pansharpening merges the multispectral (MS) and the Pan imagery producing a multispectral data set with the spatial resolution of the Pan band. The module is based on the least number of squares to an approximate gray-value relationship between the original multispectral image, panchromatic image, and fused image (PCI Geomatics 2005; Zhang 2002). This model retains as close to the original spectral values from the MS bands as possible.

Two sets of ground reference data were used to assess the mapping of leafy spurge in the park. One set was used to interpret the classification (Set 1), and the other was reserved for accuracy assessment (Set 2). Set 1 (Fig. 2) was collected during the summer of 2001 . Field crews at TRNP trained in 
vegetation identification and Global Positioning System (GPS) field procedures conducted detailed ground surveys of major leafy spurge infestation areas. Using a sampling scheme of $32 \times$ $32 \mathrm{~m}$ grid cells, the corners were marked with survey flagging using GPS equipment in several areas containing extensive leafy spurge infestations. Once a sizeable area had been identified, the field crew did a cursory check in the cell of interest for the presence of leafy spurge. If there was no leafy spurge, the team moved on to the next cell. When leafy spurge was found, the perimeter of the spurge area was marked and measured with the GPS. Aerial photographs used for the field reference maps along the Little Missouri River floodplain and the Cottonwood Campground area. The crews estimated and then recorded the spurge density and cover and also noted the associated native vegetation present, either by occurrence or percentage on the plot. This was done so the Park would have an idea if the leafy spurge turned the cell into a complete monotypic stand, or if there was a chance the natives might return after management of the leafy spurge infestations was under way (Trammel and Butler 1995). Each grid cell was labeled with the percentage of leafy spurge present: $>50 \%, 40 \%-49 \%, 30 \%-39 \%, 20 \%-$ $29 \%, 10 \%-19 \%$, and $<10 \%$ leafy spurge. The density classification was based on a field survey done earlier of 6 randomly selected $32 \times 32 \mathrm{~m}$ cells. Within each sample cell a Daubenmire Square was randomly placed 30 times and then visually surveyed for leafy spurge. Each area was labeled with a percentage cover calculation based on agreement between all field crew members, project logistical coordinator, and project supervisor providing standardized ideas of percent cover properties between all parties.

The ground reference dataset, Set 2 (Fig. 3), was made up of five hundred fifty $3 \times 5 \mathrm{~m}$ plots and used to geographically document the presence/absence of leafy spurge, as well as to produce detailed estimates of crown cover (through stem counts) and biomass for leafy spurge and associated native vegetation types. Plots containing leafy spurge were a combination of known bio-control-measure locations and stratified random samples from areas previously mapped as leafy spurge, but where no biological control agents were released. Plots not containing leafy spurge were randomly selected from a buffer zone extending $250 \mathrm{~m}$ in all directions from previously mapped leafy spurge infestations. All points were georeferenced using GIS technology. Each point was labeled as either spurge or no spurge. These points were used in the accuracy assessment of the unsupervised classification runs.

As seen in Figures 2 and 3, there is some overlap between some of the points in Set 1 and Set 2 along the Little Missouri River. Since the data sets were collected independently and were not statistically random, no attempt was made to exclude any overlapping points. This could have led to some misclassification or errors in the accuracy assessment if, due to the $30 \mathrm{~m}$ pixel resolution, one of the ground reference points in one set was labeled spurge and in the other set the same area was labeled as no spurge. With the scarcity of ground reference information all points were used as they were labeled.

An unsupervised classification using the Isodata algorithm was selected to map the leafy spurge. The unsupervised approach was used because of the lack of comprehensive ground reference data that is needed for a supervised classification approach. The ground reference data in Set 1 only told the percentage of leafy

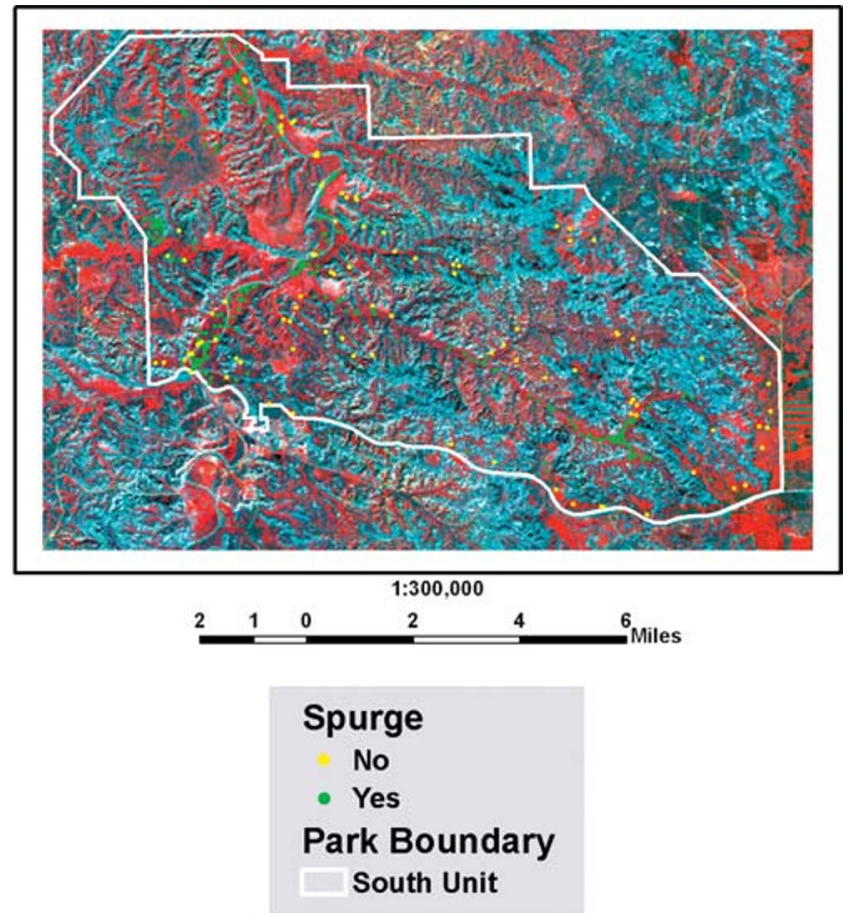

Figure 3. Ground reference Set 2, point locations of $3 \times 5 \mathrm{~m}$ grid indicating presence or absence and crown cover of leafy spurge.

spurge with each grid cell: $>50 \%, 40 \%-49 \%, 30 \%-39 \%$, $20 \%-29 \%, 10 \%-19 \%$, and $<10 \%$ leafy spurge. There were no data collected on any other land cover types.

The Isodata algorithm is a standard form of unsupervised classification and readily available in commercial image processing programs. The Isodata classifier is an extension of the $\mathrm{K}$-means algorithm. The difference between the 2 classifiers is that after each iteration the Isodata algorithm statistically examines each cluster and applies the following 3 criteria: 1 ) clusters having too large a standard deviation are split to form 2 small clusters, 2) clusters that are too similar are merged into a single cluster, and 3) clusters with too few pixel members are discarded (Research Systems, Inc 2001). A supervised approach requires extensive fieldwork and samples of each feature type found in the scene, and these were not available for this study. Four different processing runs with different band combinations were used to determine which band combinations produced the best results. (See Table 1 for spectral ranges and description of bands.)

The 4 different Landsat band combination images were generated to see if one set of bands produced better results than the other. The combination included: bands $1-5 ; 1-5$ plus 8 (Pan); $1-5,7$; and $1-5,7$ plus 8 (Pan). The same parameters were used for each Isodata run: a maximum of 50 classes, a minimum of 5 classes, and a maximum of 50 iterations were requested from the Isodata algorithm to capture the variety and character of the area and to ensure the greatest potential for identifying leafy spurge. Interpretation of the output began with analyzing the mean histogram plots for each class to discover how well the parameters were able to distinguish features. The resulting classifications were interpreted into several broad classes by analyzing the histograms of the bands. These classes included water, water/shadow; several broad vegetation groupings, such 
as grassland, trees, and shrubs; soil; and bright responses from rock outcrops and roads. These general classes were identified to make it easier to navigate around the classified images. The ground reference polygons (Set 1) were overlain on each classification, and if a class had any spurge pixels from Set 1 in it, that class was classified as spurge. All other classes were then classified as not spurge. The main goal of the project was to identify areas in the park that could be potential leafy spurge areas, so all percentages were included in the classification. Because of the inherent nature of the $30 \mathrm{~m}$ Landsat pixels to contain a mixture of features including those pixels with less than $30 \%$ leafy spurge could end up misclassifying many pixels. The final step in the interpretation was to aggregate the 50 classes into the final 2 classes-potential spurge and no spurge.

\section{RESULTS AND DISCUSSION}

The overall accuracies of the Isodata classification were lower than anticipated. A confusion matrix was used to examine and understand the accuracies of the different classifications tested. A confusion matrix contains information about actual and predicted classifications done by a classification system. Using a confusion matrix, a number of accuracy measures can be calculated. The classified image and the set of ground reference data (Set 2) are used to create a cross-tabulation of occurrence frequencies. However, when the confusion matrix reports were examined in more detail (Campbell 1987; Research Systems, Inc 2001; Congalton 2004), we found indications as to where the classifications did not perform well. At the $30 \mathrm{~m}$ resolution, the band combination image of $1-5,7$ actually had a better overall accuracy $(63.0556 \%)$ than the band combination image of $1-5(62.500 \%)$. This was surprising since at the pansharpened, higher spatial resolution of the $15 \mathrm{~m}$ the band 1-5, 8 image had a much better accuracy $(66.2100 \%)$ than the band $1-5,7,8$ image. This was not surprising since band 7 (see Table 1) is best suited for mineral and rock discrimination rather than vegetation. Overall, the higher resolution images had higher overall accuracies. The kappa coefficient values were higher in the images without band 7 at both spatial resolutions. The kappa value is a measure of the agreement between classification and reference data with the agreement due to chance removed. None of the kappa values in any of the images were very high. Landis and Koch (1977) ranked the kappa values, ranging from -1 to 1, into 3 groups: 1) those greater than 0.80 represented strong agreement between the classification and reference data; 2) those between 0.40 and 0.80 represented moderate agreement; and 3 ) those less than 0.40 represented poor agreement. The low kappa also was a product of classifying the imagery into just 2 classes. If there had been more classes, the kappa values probably would have been higher.

Other measurements from the confusion matrix resulting from the accuracy assessment include the producer's and corresponding omission accuracy and the user's and corresponding commission accuracy (see Table 2). The producer's accuracy tells the producer of the classification how well a certain area is classified. The producer accuracy is the ratio correctly classified pixels over the total number of ground truth pixels. The omission errors are 1 minus the producer's accuracy and represents pixels that belong to the ground truth class but the classification techniques failed to put them in the correct class. The user's accuracy is a reliability measure indicating the probability that a pixel classified on the map actually represents that category on the ground. The commission errors represent those pixels belonging to another class that are labeled as belonging to the class of interest. The producer's accuracy for all the images was quite high for correctly identifying leafy spurge and ranged from $83.72 \%$ to $95.35 \%$ and for correctly identifying no spurge ranged from $18.89 \%$ to $41.11 \%$. The user's accuracy for correctly classifying the spurge class ranged from $62.09 \%$ to $67.08 \%$ and for correctly classifying the no spurge ranged from $61.54 \%$ to $73.91 \%$. The user's accuracy for correctly identifying spurge correlated with the overall accuracies for the images. Again the pansharpened images had higher accuracies than the $30 \mathrm{~m}$ resolution and the images without band 7 were better than those with band 7. On the other hand the producer's accuracy for classifying the spurge was highest with the images that had band 7 in both the pansharpened and $30 \mathrm{~m}$ resolution images.

All the overall accuracies were not as high as one would want if using Landsat as the only source (even when pan sharpened) for monitoring leafy spurge. Identifying and monitoring single species, such as leafy spurge, with Landsat is difficult. By the time the plant has spread to confidently identify it with Landsat, it has already spread too far for monitoring. Managers need to monitor an outbreak when it is just beginning and Landsat is too low a resolution to detect small patches. One possible factor in the low overall accuracy might be the date selection. When mapping any type of vegetation, acquiring the image at the correct phenological stage is vital for having the best chances of correctly mapping the features. This is especially true with leafy spurge. It has been demonstrated by Anderson et al. (1993) and Everitt et al. (1995) that late May to early June is the best time to distinguish leafy spurge. During this period bract formation has occurred and bract orientation is more visible from aerial and satellite platforms. During this time period, leafy spurge has significantly higher reflectance measurements in the near-infrared band and visible red band than do associated vegetation and soil. The Landsat image was acquired on 6 July 2001 and was perhaps a little late in the season for the leafy spurge bracts to be in full bloom. Advanced image processing techniques, such as a subpixel classification (Parker-Williams and Hunt 2004) or an object-based approach, may increase the detection of leafy spurge with Landsat. These techniques typically require an experienced remote sensing analyst and add-on modules to software packages that makes the methodologies less appealing to site mangers.

Another potential consideration to lower mapping accuracies of spurge is the misidentification of agricultural fields as leafy spurge. Actively growing fields have spectral characteristics similar to those of leafy spurge. The eastern part of the Landsat image also contained agricultural cropland, and much of the cropland was labeled as leafy spurge. This was not an issue in this accuracy assessment because there were no reference points in the agricultural fields, but it could have been. In the future, care must be taken to mask out the active agricultural fields from any leafy spurge analysis.

Just as selecting the best date possible for the imagery is extremely important, so is having high-quality ground reference data. The Set 1 ground reference data was collected for the 
Table 2. a,b,c,d. Results of accuracy assessment for 4 different classification runs (bands 1-5, bands 1-5, 7; bands 1-5, 8; and bands 1-5, 7, 8).

a) Confusion matrix: Bands 1-5; overall accuracy $=(225 / 360) 62.5000 \%$; kappa coefficient $=0.1803$

Classified data Ground reference data

\begin{tabular}{|c|c|c|c|c|c|c|c|c|}
\hline Class & \multicolumn{2}{|l|}{ Spurge (pixels) } & Spurge (\%) & No spurge (pixels) & \multicolumn{2}{|c|}{ No spurge (\%) } & \multirow{2}{*}{$\begin{array}{c}\text { Total (pixels) } \\
282\end{array}$} & \multirow{2}{*}{$\frac{\text { Total }(\%)}{78.33}$} \\
\hline Spurge & 177 & & 85.51 & 105 & & & & \\
\hline No spurge & 30 & & 14.49 & 48 & & & 78 & 21.67 \\
\hline Total & 207 & & 100.00 & 153 & & & 360 & 100.00 \\
\hline Class & $\begin{array}{l}\text { Commission } \\
\text { (pixels) }\end{array}$ & $\begin{array}{c}\text { Commission } \\
(\%)\end{array}$ & $\begin{array}{c}\text { Omission } \\
\text { (pixels) }\end{array}$ & $\begin{array}{l}\text { Omission } \\
(\%)\end{array}$ & $\begin{array}{l}\text { User acc. } \\
\text { (pixels) }\end{array}$ & $\begin{array}{l}\text { User acc. } \\
(\%)\end{array}$ & $\begin{array}{l}\text { Prod. acc. } \\
\text { (pixels) }\end{array}$ & $\begin{array}{c}\text { Prod. acc. } \\
(\%)\end{array}$ \\
\hline Spurge & $105 / 282$ & 37.23 & $30 / 207$ & 14.49 & $177 / 282$ & 62.77 & $177 / 207$ & 85.51 \\
\hline No spurge & $30 / 78$ & 38.46 & $105 / 153$ & 68.63 & $48 / 78$ & 61.54 & $48 / 153$ & 31.37 \\
\hline
\end{tabular}

b) Confusion matrix: Bands 1-5, 7; overall accuracy $=(227 / 360) 63.0556 \%$; kappa coefficient $=0.1744$

Classified data

Ground reference data

\begin{tabular}{|c|c|c|c|c|c|c|c|c|}
\hline Class & \multicolumn{2}{|c|}{ Spurge (pixels) } & Spurge (\%) & No spurge (pixels) & \multicolumn{2}{|c|}{ No spurge $(\%)$} & Total (pixels) & Total (\%) \\
\hline Spurge & \multicolumn{2}{|c|}{190} & 91.79 & 116 & \multicolumn{2}{|c|}{75.82} & 306 & 85.00 \\
\hline No spurge & \multicolumn{2}{|c|}{17} & 8.21 & 37 & \multicolumn{2}{|c|}{24.18} & 54 & 15.00 \\
\hline Total & \multicolumn{2}{|c|}{207} & 100.00 & 153 & \multicolumn{2}{|c|}{100.00} & 360 & 100.00 \\
\hline Class & $\begin{array}{l}\text { Commission } \\
\text { (pixels) }\end{array}$ & $\begin{array}{c}\text { Commission } \\
(\%)\end{array}$ & $\begin{array}{l}\text { Omission } \\
\text { (pixels) }\end{array}$ & $\begin{array}{l}\text { Omission } \\
(\%)\end{array}$ & $\begin{array}{l}\text { User acc. } \\
\text { (pixels) }\end{array}$ & $\begin{array}{c}\text { User acc. } \\
(\%)\end{array}$ & $\begin{array}{c}\text { Prod. acc. } \\
\text { (pixels) }\end{array}$ & $\begin{array}{c}\text { Prod. acc. } \\
(\%)\end{array}$ \\
\hline Spurge & $116 / 306$ & 37.91 & $17 / 207$ & 8.21 & $190 / 306$ & 62.09 & $190 / 207$ & 91.79 \\
\hline No spurge & $17 / 54$ & 31.48 & $116 / 153$ & 75.82 & $37 / 54$ & 68.52 & $37 / 153$ & 24.18 \\
\hline
\end{tabular}

c) Confusion matrix: Bands 1-5, 8; overall accuracy $=(145 / 219) 66.2100 \%$; kappa coefficient $=0.2624$

Classified data Ground reference data

\begin{tabular}{|c|c|c|c|c|c|c|c|c|}
\hline Class & \multicolumn{2}{|l|}{ Spurge (pixels) } & Spurge (\%) & No spurge (pixels) & \multicolumn{2}{|c|}{ No spurge (\%) } & \multirow{2}{*}{$\frac{\text { Total (pixels) }}{161}$} & \multirow{2}{*}{$\frac{\text { Total }(\%)}{73.52}$} \\
\hline Spurge & 108 & & 83.72 & 53 & & & & \\
\hline No spurge & 21 & & 16.28 & 37 & & & 58 & 26.48 \\
\hline Total & 129 & & 100.00 & 90 & & & 219 & 100.00 \\
\hline Class & $\begin{array}{l}\text { Commission } \\
\text { (pixels) }\end{array}$ & $\begin{array}{c}\text { Commission } \\
(\%)\end{array}$ & $\begin{array}{l}\text { Omission } \\
\text { (pixels) }\end{array}$ & $\begin{array}{l}\text { Omission } \\
(\%)\end{array}$ & $\begin{array}{c}\text { User acc. } \\
\text { (pixels) }\end{array}$ & $\begin{array}{c}\text { User acc. } \\
(\%)\end{array}$ & $\begin{array}{l}\text { Prod. acc. } \\
\text { (pixels) }\end{array}$ & $\begin{array}{c}\text { Prod. acc. } \\
(\%)\end{array}$ \\
\hline Spurge & $53 / 161$ & 32.92 & $21 / 129$ & 16.28 & $190 / 306$ & 67.08 & $108 / 129$ & 83.72 \\
\hline No spurge & $21 / 58$ & 36.21 & $53 / 90$ & 58.89 & $37 / 58$ & 63.79 & $37 / 90$ & 41.11 \\
\hline
\end{tabular}

d) Confusion matrix: Bands 1-5, 7, 8; overall accuracy $=(140 / 219) 63.9269 \%$; kappa coefficient $=0.1604$

\begin{tabular}{|c|c|c|c|c|c|c|c|c|}
\hline \multirow{2}{*}{$\begin{array}{l}\text { Classified data } \\
\text { Class }\end{array}$} & \multicolumn{8}{|c|}{ Ground reference data } \\
\hline & \multicolumn{2}{|c|}{ Spurge (pixels) } & Spurge (\%) & No spurge (pixels) & \multicolumn{2}{|c|}{ No spurge $(\%)$} & Total (pixels) & Total $(\%)$ \\
\hline Spurge & \multicolumn{2}{|c|}{123} & 95.35 & 73 & \multicolumn{2}{|c|}{81.11} & 196 & 89.50 \\
\hline Total & \multicolumn{2}{|c|}{129} & 100.00 & 90 & \multicolumn{2}{|c|}{100.00} & 219 & 100.00 \\
\hline Class & $\begin{array}{l}\text { Commission } \\
\text { (pixels) }\end{array}$ & $\begin{array}{c}\text { Commission } \\
(\%)\end{array}$ & $\begin{array}{l}\text { Omission } \\
\text { (pixels) }\end{array}$ & $\begin{array}{l}\text { Omission } \\
(\%)\end{array}$ & $\begin{array}{l}\text { User acc. } \\
\text { (pixels) }\end{array}$ & $\begin{array}{c}\text { User acc. } \\
(\%)\end{array}$ & $\begin{array}{c}\text { Prod. acc. } \\
\text { (pixels) }\end{array}$ & $\begin{array}{c}\text { Prod. acc. } \\
(\%)\end{array}$ \\
\hline No spurge & $6 / 23$ & 26.09 & $73 / 90$ & 81.11 & $17 / 23$ & 73.91 & $17 / 90$ & 18.89 \\
\hline
\end{tabular}


overall project in mind, but specifically aimed at the hyperspectral imagery (AVIRIS and CASI) analyzed by other scientists on the project. The Set 2 ground reference data points used for the accuracy assessment may have introduced biases. Ideally, points for accuracy assessment are randomly generated from within the study area and represent all the features present. This was not the case with this study. The points were not randomly selected but rather came from field measurements of $3 \times 5 \mathrm{~m}$ plots by a scientist who chose the points because of the likelihood that spurge was either present or not present. However, this situation is not unique. Accuracy assessment is typically very time consuming, adds to the costs of a project, and is not done if an alternative source of data can be found. There were also some obvious mismatches in classification owing to the scale of the sample grids and the spatial resolution of the Landsat imagery. It is conceivable that a site with no leafy spurge, in the $3 \times 5 \mathrm{~m}$ plots, may actually contain leafy spurge in the larger $30 \times 30 \mathrm{~m}$ or $15 \times 15 \mathrm{~m}$ Landsat pixel. Another potential problem with the resolution of Landsat occurs when a pixel is overwhelmed and dominated by a single feature; for example, when pixels at stream banks (mixture of land and water) are classified as water or pixels are classed as trees because of the canopy. This characteristic indicates a potential problem when using Landsat to map a single species, such as leafy spurge, where the occurrence of the plant is localized and in small patches or is dominated by another feature.

\section{MANAGEMENT IMPLICATIONS}

As part of TEAM Leafy Spurge, the USGS was evaluating multisensor platforms in an effort to develop techniques and protocols for resource managers in the TRNP to map the extent of leafy spurge. Such a protocol would have application well beyond the park area. This particular part of that study investigated the Landsat 7 ETM+ sensor. The techniques used are readily available from commercial software and easy to reproduce by park personnel for monitoring leafy spurge. The Landsat imagery is cost effective and easy to handle and process. But because of the $30 \mathrm{~m}$ or $15 \mathrm{~m}$ spatial resolution of the satellite, its pixels are typically composed of composite features. A single pixel may contain several features, or a single feature may overwhelm the signal and carry that reflectance response collected by the satellite. The pansharpened $(15 \mathrm{~m})$ imagery performed better than the $30 \mathrm{~m}$ imagery, but not by much. The other higher resolution imagery used in the project also had better accuracy. The issues with the different sets of ground reference data points out the importance of taking the time and expending the money to collect ground reference data specific to the imagery being used. This is especially important with mapping a single species such as leafy spurge.

The techniques presented in this paper may not yield the detailed mapping necessary for monitoring control measures for leafy spurge, but they do demonstrate the ability to map vegetation types most likely to be leafy spurge over large regions. It is also important to mask out any agricultural areas before classifying the Landsat imagery. Mapping regions with Landsat could help land managers identify unknown sites that may require more intensive investigation. The appearance of new commercial, high spatial resolution, multispectral satellites offers another source of imagery to attack the problem of leafy spurge. A two-tiered approach could be used. Landsat could be used for the regional view of the extent and to identify potential hot spots of leafy spurge, and then the high-resolution imagery (spatial and/or spectral) could be used in the known areas or newly identified areas to monitor the situation more closely. This approach could allow managers to obtain data more frequently (Landsat) and help focus the more expensive acquisitions of higher-resolution data.

\section{LITERATURE CITED}

Anderson, G. L., J. H. Everitt, D. E. Escobar, N. R. Spencer, and R. J. Andrascik. 1996. Mapping leafy spurge (Euphorbia esula) infestations using aerial photography and geographic information systems. Geocarto International 11:81-89.

Anderson, G. L., J. D. Hanson, and R. H. HaAs. 1993. Evaluating LANDSAT thematic mapper derived vegetation indices for estimating aboveground biomass on semi-arid rangelands. Remote Sensing of the Environment45:165-175.

Anderson, G. L., C. W. Prosser, S. Hager, and B. Foster. 1999. Change detection of leafy spurge (Euphorbia esula) infestations using aerial photography and GIS. In: The American Society of Photogrammetry and Remote Sensing Proceedings of the 17th Biennial Workshop on Color Photography and Videography in Resource Assessment, Reno, NV. p 223-230.

ANDRASCIK, R. J. 1994. A post workshop review: discussion, process, and highlights for developing a leafy spurge strategic management plan within Theodore Roosevelt National Park. In: Proceedings: Leafy Spurge Strategic Planning Workshop Theodore Roosevelt National Park, Dickinson, ND, March 29-30, 1994. C. H. Schmidt [ED.]. Agricultural Experimental Station, NSDU Extension Service, NDSU, Fargo, ND. p 109-117. Available at: http:// www.lib.ndsu.nodak.edu/research/subjects/ag/spurge_wl/spurge/pdffiles/ SYMPOSIU/TRNPproc/32and94.pdf. Last Accessed: 12 June 2006.

CampBelL, J. B. 1987. Introduction to remote sensing. New York, NY: Guilford Press. $551 \mathrm{p}$.

Carneggie, D. M., B. J. Schrumpf, and D. M. Mouat. 1983. Rangeland applications. In: R. N. Colwell [ED.]. Manual of remote sensing. Falls Church, VA: American Society of Photogrammetry and Remote Sensing. p 2325-2364.

Congalton, R. G. 2004. Putting the map back in map accuracy assessment. In: R. S. Lunetta and J. G. Lyon [EDS.]. Remote sensing and GIS accuracy Assessment. Boca Raton, FL: CRC Press LLC. 274 p.

Everitt, J. H., G. L. Anderson, D. E. Escobar, M. R. Davis, N. R. Spencer, and R. J. ANDRASCIK. 1995. Use of remote sensing for detecting and mapping leafy spurge (Euphorbia esula). Weed Technology 9:3:599-60.

EveritT, J. H., D. E. Escobar, and M. R. Davis. 2001. Reflectance and image characteristics of selected noxious rangeland species. Journal of Range Management 54:A106-A120.

Landis, J., AND G. KocH. 1977. The measurement of observer agreement for categorical data. Biometrics 33:159-174.

NASA Goddard Space Flight Center. 2005. Landsat 7 Compositor. Web curator: Rocchio, L. Responsible NASA Official: Williams, D. Available at: http:// landsat.gsfc.nasa.gov/education/compositor/. Last updated: 21 December 2005. Greenbelt, MD. Last accessed 12 June 2006.

Parker-Williams, A. E., and E. R. Hunt, JR. 2004. Accuracy assessment for detection of leafy spurge with hyperspectral imagery. Journal of Range Management 57:106-112.

PCI Geomatics. 2005. OrthoEngine High Resolution Model and Pansharpening Model, Edition v. 9.1.7. January 2005. Software documentation and online help. $\mathrm{PCl}$ Geomatics. Richmond Hill, Ontario, Canada. http://pcigeomatics.com.

ReSearch Systems, Inc. 2001. ENVI User's Guide. Boulder, CO. 948 p.

Trammel, M. A., and J. L. Butler. 1995. Effects of exotic plants on native ungulate use of habitat. Journal of Wildlife Management 59(4):808-816.

ZHANG, Y. 2002. A new automatic approach for effectively fusing Landsat 7 images and IKONOS images. Geoscience and Remote Sensing Symposium; 24-28 June 2002; Toronto, Canada. Institute of Electrical and Electronics Engineers, Inc./ International Geoscience and Remote Sensing Society, Vol. 4, pp 2429-2431. 